\title{
The recent invasion of Rutilus rutilus (L.) (Pisces: Cyprinidae) in a large South- Alpine lake: Lago Maggiore
}

\author{
Pietro VOLTA* and Niels JEPSEN ${ }^{1)}$ \\ CNR-Institute of Ecosystem Study, L.go Tonolli 50, I-28922 Verbania Pallanza, Italy \\ ${ }^{1)}$ European Commission - Joint Research Centre, Institute for Environment and Sustainability, Via Enrico Fermi, I-21020 Ispra, Italy \\ *e-mail correspondig author: p.volta@ise.cnr.it
}

\begin{abstract}
Very recently, a common cyprinid fish species at northern latitude, the roach (Rutilus rutilus L.) has been observed in the large south-alpine Lago Maggiore for the first time. The colonization of the lake has the characteristics of an invasion. In order to investigate this new fish population, benthic multi-mesh and commercial gill nets were used to sample fish in a wide gulf in the central part of the lake (Golfo Borromeo) from February to October 2006. In total 779 roach (TL: $5.5-38.8 \mathrm{~cm}$ ) were caught, aged, sexed and stomach analyzed. Fecundity was assessed by counting the eggs in ripe gonads of females of age 3 and 4 . The roach have become clearly the dominant species in the catches, constituting over $70 \%$ of the biomass and $70 \%$ of the numbers caught. None of the roach exceeded 8 years in age. They grow very fast $\left(\Phi^{\prime}=2.55\right)$ and have high fecundity $\left(F_{\text {abs }}=13740 \pm 4700\right.$ S.D. at age 3 and $F_{a b s}=14768 \pm 5642$ S.D. at age 4). The diet spectrum is wide and characterized by a strong seasonality. In early spring algae (benthic and planktonic algae), benthos and detritus prevail, whereas in summer zooplankton is the most frequent food item. In autumn roach switch back to benthos and detritus. Algae occur more frequently in young specimens while zooplankton, benthos and detritus in adults. The roach population is practically unimpacted by fishing. The minimum legal mesh size (25 mm) of gillnets, used by commercial fishermen, selects roach at the mean $L_{T}$ of $21.2 \mathrm{~cm}$, which is over its length at maturity. The results suggest that roach established a viable population in Lago Maggiore less than a decade ago and rapidly became one of the dominant (if not the dominant) fish species. The possible consequence for the fish fauna in general and for the ecological status of the whole lake is briefly discussed.
\end{abstract}

Key words: Gill nets, deep lakes, exotic species, cascade effects

\section{INTRODUCTION}

The structure of fish assemblages in lakes depend on multiple ecological processes over varying temporal and spatial scales. Factors that have been identified as important in structuring northern temperate fish assemblages are physicochemical factors (Tonn \& Magnusson 1982; Rahel 1986; Persson 1997), productivity (Marshall \& Ryan 1987; Gibson \& Headrich 1988), lake depth and lake size (Rahel 1986; Jackson \& Harvey 1989). Human alterations to aquatic ecosystems such as habitat degradation and introduction of exotic species can also have profound effects on fish assemblages (Cambray 2003; Goren \& Galil 2005).

During the last 50 years, Italian lakes have been heavily affected by anthropogenic pressures such as organic (Mosello \& Giussani 1997) and chemical pollution (Galassi et al. 1981; Volta et al. 2008) but also by erroneous fish management and stocking practices often characterized by the introduction of alien species. After the 1950s the presence of exotic species in Italy increased rapidly and the adverse effect of these invaders is now a major problem for the local fish fauna (Bianco 1998; Bianco \& Ketmeier 2001; Gherardi et al. 2008).

Roach Rutilus rutilus (L.) is one of the most recent exotic species appearing in Italian freshwaters. Origi- nally restricted to Central and Eastern Europe (Banarescu et al. 1971), roach has now spread to most of Europe (Kottelat \& Freyhof 2007). In Italy it was first introduced in Tuscany for recreational purposes and then spread to the Po River basin (Delmastro \& Balma 1991) where it is now found in large, deep subalpine lakes, reservoirs, rivers as well as in several shallow lakes. Many aspects of the biology of roach populations of central and northern Europe have been investigated and a wide and detailed literature is available (e.g., Kempe 1962; Hellawell 1972; Ponton \& Gerdeaux 1987; Chappaz et al. 1990; Garcia-Berthou 1999). However, the knowledge on (invasive) roach populations in southern countries is scarce and fragmentary (Garcia-Berthou 1999; Guthruf 2002).

The aim of this study was to investigate a newly established roach population in a large lake. The results are compared with those of roach populations in other European countries and possible mechanisms of competition with native species are discussed.

\section{MATERIALS AND METHODS}

\subsection{Study area}

Lago Maggiore, a warm-monomictic pre-alpine lake of $212.5 \mathrm{~km}^{2}$, is situated in north-western Italy at an altitude of $193.5 \mathrm{~m}\left(45^{\circ} 57^{\prime} \mathrm{N}, 8^{\circ} 33^{\prime} \mathrm{W}\right.$, Greenwich). Its 
Tab. 1. Fish species composition of Lago Maggiore. For non native species the estimated (or documented) time of introduction is indicated.

\begin{tabular}{ll}
\hline Native & Non-native \\
\hline Lake trout (Salmo trutta Linneus 1758) & Common whitefish (Coregonus lavaretus Linneus 1758) (1861) \\
Landlocked shad (Alosa agone Kottelat \& Freyhof 2007) & Alpine charr (Salvelinus umbla Linneus 1758) (1896) \\
Pike (Esox lucius Linneus 1758) & Pumpkinseed (Lepomis gibbosus Linneus 1758) (1930) \\
Perch (Perca fluviatilis Linneus 1758) & Largemouth bass (Micropterus salmoides Linneus 1758) (1930) \\
Carp (Cyprinus carpio Linneus 1758) & Black bullhead (Ameiurus melas Rafinesque 1820) (1930) \\
Tench (Tinca tinca Linneus 1758) & Whitefish (Coregonus macrophthalmus Nusslin 1882) (1949) \\
Chub (Squalius squalus Kottelat \& Freyhof 2007) & Pikeperch (Sander lucioperca Linneus 1758) (1990) \\
Bleak (Alburnus alburnus Linneus 1758) & European catfish (Silurus glanis Linneus 1758) (1990) \\
Rudd (Scardinius erythrophthalmus Linneus 1758) & Crucian carp (Carassius carassius Linneus 1758) (1990) \\
Minnow (Phoxinus phoxinus Linneus 1758) & Roach (Rutilus rutilus Linneus 1758) (1993) \\
Italian nasus (Chondrostoma söetta Linneus 1758) & Bitterling (Rhodeus amarus Linneus 1758) (1995) \\
Triotto (Rutilus aula Bonaparte 1841) & Ruffe (Gymnocephalus cernuus Linneus 1758) (1995) \\
Danube roach (Rutilus pigus Lacepède 1803) & \\
Padanian barbel (Barbus plebejus Linneus 1758) & \\
Freshwater blenny (Salaria fluviatilis Asso 1801) & \\
Goby (Padogobius bonelli Bonaparte 1846) & \\
Bullhead (Cottus gobio Linneus 1758) & \\
Stoneloach (Cobitis tenia Linneus 1758) & \\
Eel (Anguilla anguilla Linneus 1758) & \\
Burbot (Lota lota Linneus 1758) & \\
\hline
\end{tabular}

maximum depth is $370 \mathrm{~m}$ and mean depth is $177 \mathrm{~m}$. From being naturally oligotrophic, the lake underwent human-induced eutrophication starting from the middle of 1960s. It approached mesotrophy at the end of 1970s (Mosello \& Ruggiu 1985), when in-lake total phosphorus (TP) concentration reached its maximum value ( $c a$ $40 \mu \mathrm{g} \mathrm{L}^{-1}$ at spring overturn). As a result of improved sewage treatment and phosphorus reduction in detergents, $\mathrm{TP}$ in the lake decreased to about $12 \mu \mathrm{g} \mathrm{L}{ }^{-1}$. In $1942 \mathrm{a}$ hydropower facility was build at the outlet of the lake, causing frequent water level fluctuations of 1-2 meters.

Thirty-two fish species inhabit the Lake (Tab. 1) of which only twenty are native. A century ago, the lake sustained a substantial fishery with over 150 commercial fishers. The number of commercial fishermen decreased from 150 in 1995 to 39 in 2006 (Volta \& Romanò 2007). This decline was mainly caused by a temporary stop for commercial fishing due to a severe case of DDT pollution of the lake (i.e., Bettinetti et al. 2006). Fishing on whitefish, landlocked shad, bleak and rudd was prohibited, because contaminants exceeded the threshold for human consumption $\left(0.05-0.1 \mathrm{mg} \mathrm{kg}^{-1}\right.$ b.w. $\Sigma$ DDT depending on lipid content). Thus, fishing only on littoral species, which are of secondary importance, was not sufficient to make an income for the commercial fishers.

\subsection{Sampling procedures and data acquisition}

The area sampled in this study was confined to a large $\left(c a 20 \mathrm{~km}^{2}\right)$ and deep (max depth $\left.140 \mathrm{~m}\right)$ gulf in the central region of the lake. Benthic multimesh gillnets (Lundgren, Sweden) were used in February, May, July and October 2006 and additional roach were obtained from commercial benthic gillnets $(25 \mathrm{~mm}, 34$ $\mathrm{mm}$ and $40 \mathrm{~mm}$ knot-to-knot) in March, August and September 2006. Gillnets were set perpendicularly to the shore at a depth between 5 and $40 \mathrm{~m}$. Only the data from benthic multimesh gillnets was used to calculate CPUE.

Fish were measured (total length, $L_{T}$ ), weighed (total body mass, $W_{T}$ ). Sex was determined by dissection. Ten scales from the left side, just above the lateral line and under the caudal fin, were removed from each fish and used for age determination. May $1^{\text {st }}$ was chosen as the passage of the year.

\subsection{Data analysis}

The relationship between $L_{T}$ and $W_{T}$ was calculated for all specimens and for males and females separately using the allometric model:

$$
W_{T}=a \times L_{T}^{b}
$$

where $W_{T}$ is fish total body mass in grams, $L_{T}$ is total length in cm, $a$ is a constant and $b$ the allometric coefficient. Length-at-age data were used to estimate the parameters of the Von Bertalanffy (1938) growth function VBGF:

$$
L_{T}=L_{\infty}\left(1-e^{-k\left(t-t_{0}\right)}\right)
$$

where $L_{T}$ is the total length of the fish at time $\mathrm{t}, L_{\infty}$ is the ultimate length an average fish could achieve, $k$ is the growth constant which determines how fast the fish approach $L_{\infty}$ and $t_{0}$ is the hypothetical age at $L_{T}=0$. $\Phi^{\prime}$ Phi'-prime (Pauly \& Munro 1984) index was calculated to compare the growth performance of roach as:

$$
\Phi^{\prime}=\log (k)+2 \log \left(L_{\infty}\right)
$$

where $k$ and $L_{\infty}$ are parameters of VBGF.

The diet analyses were carried out for at least 10 individuals from each age group and for each sampling date. Thus a total of 280 stomachs were analyzed. Age groups were defined on the base of the number of annuli identified on the scale. The gut content was analyzed 


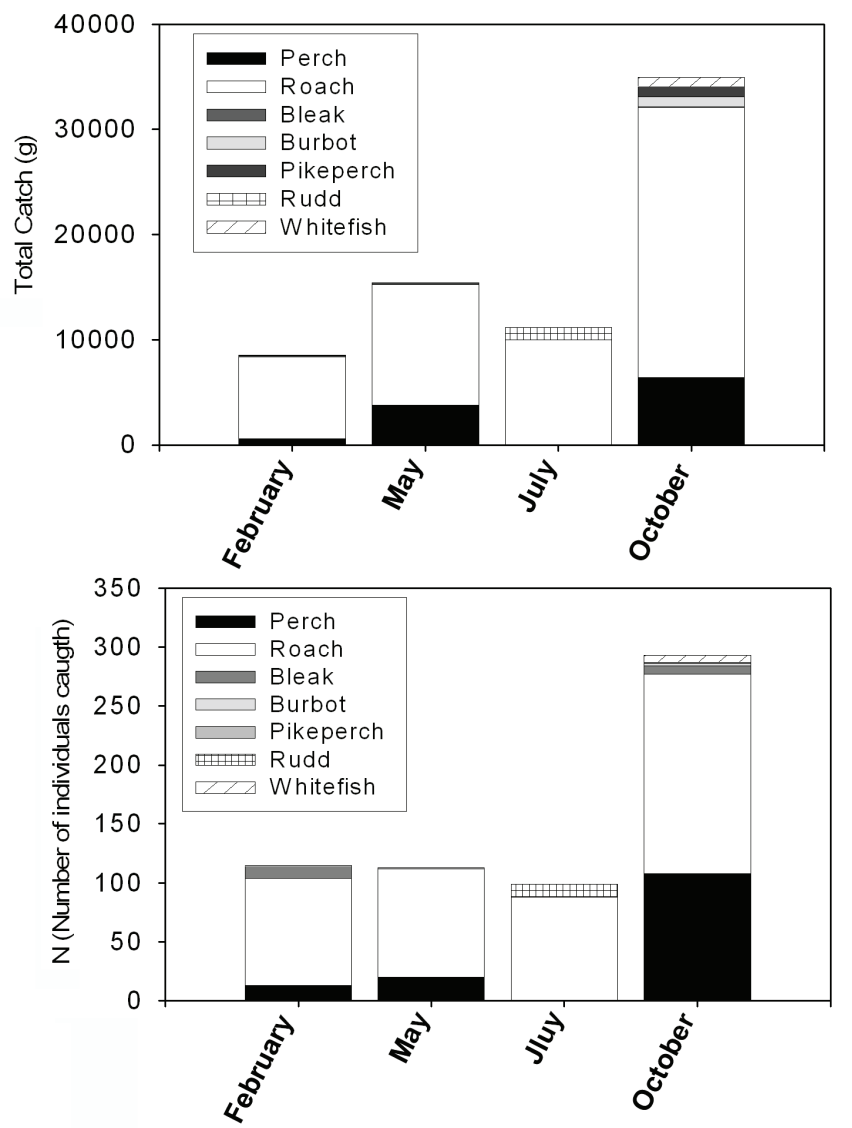

Fig. 1. Biomass and number of the fish caught in the multimesh gillnets.

under a stereomicroscope to detect prey items. For each food category the frequency of occurrence was calculated as:

$$
F \%=n \times N^{-1} \times 100
$$

where $n=$ number of guts where each category is present; $N=$ total number of guts.

Sex ratio (females:males) was determined. Gonadosomatic index $(G S I \%)$ at maturity was calculated as:

$$
\operatorname{GSI}(\%)=W_{G} \times W_{T}^{-1} \times 100
$$

where $W_{G}$ is the mass of the gonad and $W_{T}$ the total body mass of the fish. Length at first maturity $L_{m}$ was calculated according to Froese \& Binohlan (2000). Absolute and relative fecundity were also calculated by counting eggs of ripe gonads. Absolute fecundity was:

$$
F_{a b s}=W_{G} \times N \times W_{S}^{-1}
$$

where $F_{a b s}=$ absolute fecundity; $W_{G}=$ mass of the gonads; $W_{S}=$ mass of the subsample; $N=$ number of the eggs in the subsample. Relative fecundity $\left(F_{r e l}\right)$ was calculated according to:

$$
F_{r e l}=F_{a b s} \times W_{T} \times 1000
$$

where $F_{a b s}$ is the absolute fecundity and $W_{T}$ is the total body mass of the fish in grams.

The total instantaneous mortality $(Z)$ was calculated by the linearized catch curve (Sparre \& Venema 1988) using fish captured with multimesh gillnet. A rough estimation of the natural mortality rate $M$ was calculated using the empirical equation of Pauly (1980), which provide an estimate of $M$ on the base of $L_{\infty}$ and $k$ of VBGF, and the annual mean water temperature.

Differences in growth and GSI between males and females were tested by $t$-test, ANOVA and ANCOVA.

\section{RESULTS}

Seven fish species were captured in the multimesh gillnets (Fig. 1): roach (Rutilus rutilus), perch (Perca fluviatilis), burbot (Lota lota), pikeperch (Sander lucioperca), rudd (Scardinius erythrophthalmus), and whitefish (Coregonus sp.). Roach was clearly the dominant species in the catch of the multimesh gillnets and occurred on all sampling dates; 440 roach were captured in the multimesh nets where the CPUE ranged from $1100 \mathrm{~g} \mathrm{net}^{-1}$ in February to $2850 \mathrm{~g} \mathrm{net}^{-1}$ in October. A total of 339 individual roach were obtained from commercial gill nets. 
Total instantaneous mortality rate $Z$ is $0.60 \mathrm{y}^{-1}$ with a natural mortality $M$ of $0.57 \mathrm{y}^{-1}$ estimated by the equation of Pauly (1980) $\left(K=0.35\right.$ e $\left.T^{\circ}=13{ }^{\circ} \mathrm{C}\right)$, indicating very low fishing pressure.

\subsection{Size, age, sex and age distribution of roach}

In total (multimesh and commercial nets), 779 roach were captured, $403(52 \%)$ being females, 288 (37\%) males and for $88(11 \%)$, sex was not estalished. Mean age was $3.2 \mathrm{y}$ for females and $2.9 \mathrm{y}$ for males. Age and sex distribution is plotted in figure 2 .

The total length of roach ranged from 5.5 to $38.8 \mathrm{~cm}$ (mean: $20.8 \pm 5.11$ S.D.) for all individuals, 15.6 to 38.0 cm (mean: $23.4 \pm 3.1$ S.D.) for females and 14.1 to 32.8 $\mathrm{cm}$ (mean: $21.0 \pm 3.0$ S.D.) for males. Mean total body mass was $115 \mathrm{~g}($ S.D. $=70.1)$ for all roach and $142 \mathrm{~g}$ (S.D. $=65.4)$ and $110 \mathrm{~g}($ S.D. $=56.1)$ for the females and males respectively. Overall, males were significantly smaller than females ( $t$-test, $d f=689, P<0.001)$.

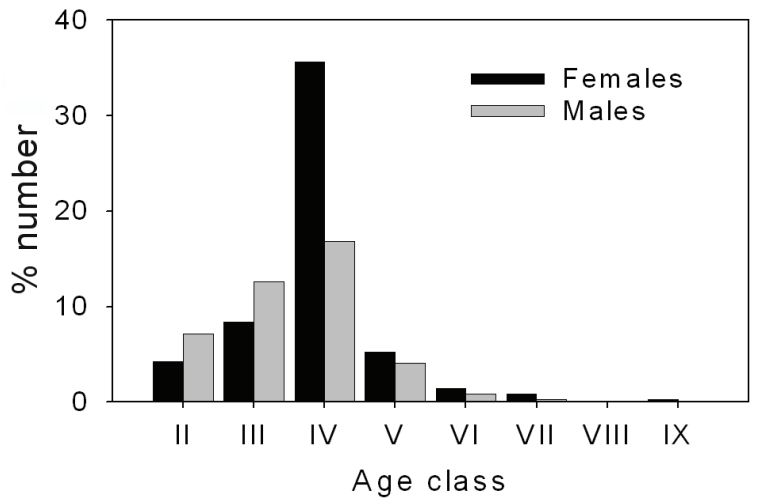

Fig. 2. Age distribution of males and females roach in the whole sample. $0^{+}$fishes (age class I) are excluded.

\subsection{Growth}

The length-weight relationship was for both sex pooled $\left(n=779, r^{2}=0.99, P<0.005\right)$, for females $(n=$ 403, $\left.r^{2}=0.99, P<0.005\right)$ and for males $\left(n=288, r^{2}=\right.$ $0.98, P<0.005)$. The high $b$ values $(>3)$ indicate a positive allometric growth. A highly significant difference was found in growth between females and males (ANCOVA, $n=691, P<0.001$, sex as factor and age as covariate).

Length at age $0^{+}$of the indistinct sample was used for the calibration of the VBGF. Asymptotic length was $35.75 \mathrm{~cm}$ (C.I. $.95 \%= \pm 0.59)$ for the total sample, and 31.40 (C.I. $95 \%= \pm 0.64$ ) for males and 36.83 (C.I. $.95 \%=$ \pm 0.62 ) females. The Von Bertalanffy growth function was:

- $\quad L_{T}=35.75\left(1-e^{-0.294(t-0.405)}\right)$ for pooled sex,

- $\quad L_{T}=36.83\left(1-e^{-0.286(t-0.305)}\right)$ for females,

- $\quad L_{T}=31.40\left(1-e^{-0.368(t-0.261)}\right)$ for males.

\subsection{Diet}

Based on scale readings, four age groups were defined. They were characterized by the presence of 1 , 2,3 and $\geq 4$ annuli. A total of 280 guts were analyzed. The percentage of full stomachs increases along the season, peaking $(99 \%)$ at the end of the summer and reaching the lowest value in winter $(70 \%)$.

The diet spectrum is wide and characterized by a strong seasonality (Fig. 3). In February and March algae (benthic and planktonic) $(100 \%)$, benthos $(75 \%)$ and detritus $(50 \%)$ prevail, whereas in summer zooplankton constitute up to $63 \%$ (July) of the diet. In autumn roach switch back to benthos and detritus while algae continue to decrease. Within benthos Dreissena polymorpha, Pisidium sp., Ostracoda and insect larvae (trichoptera and ephemeroptera) are the most frequent food items.

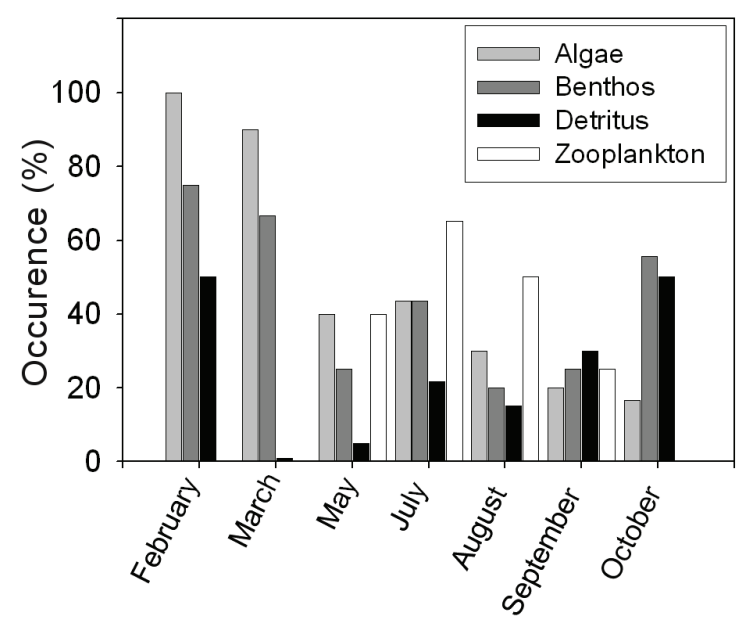

Fig. 3. Occurrence $(\%)$ of food categories in roach diet during 2006.

The only zooplankton taxon eaten is cladocerans. Daphnia sp. prevails in May (60\%), Bosmina sp. in July and August (65\%) and September (75\%). The littoral Eurycercus lamellatus occurs in May and September with the same frequency $(25 \%)$.

Food items have different importance in relation to the age (Fig. 4). Algae are dominant (60\%) in the first age group $\left(1^{+}\right.$year class) decreasing steadily until $15 \%$ in the fourth age group but benthos increases in importance with age $\left(5 \%\right.$ in $1^{+}$specimen to $55 \%$ in $\left.\geq 4^{+}\right)$. The same trend is evident for the detritus. Zooplankton occurrence is highest (35\%) in roach of group 2 and 3.

\subsection{Reproductive status}

The calculated length at maturity $L_{m}$ was $19.3 \mathrm{~cm}$ ( \pm 0.9 C.I. $95 \%)$ for females and $17.0 \mathrm{~cm}( \pm 1.3$ C.I. $.95 \%)$ for males. Mean sex ratio (females:males) was 1:0.61 and increases significantly with age (ANOVA, $P<0.05$ ). $\mathrm{GSI} \%$ at maturity differ significantly ( $t$-test, $n=40, P$ 
$<0.001)$ between females ( $15.97 \pm 5.69$ S.D. $)$ and males (3.99 \pm 2.50 S.D.).

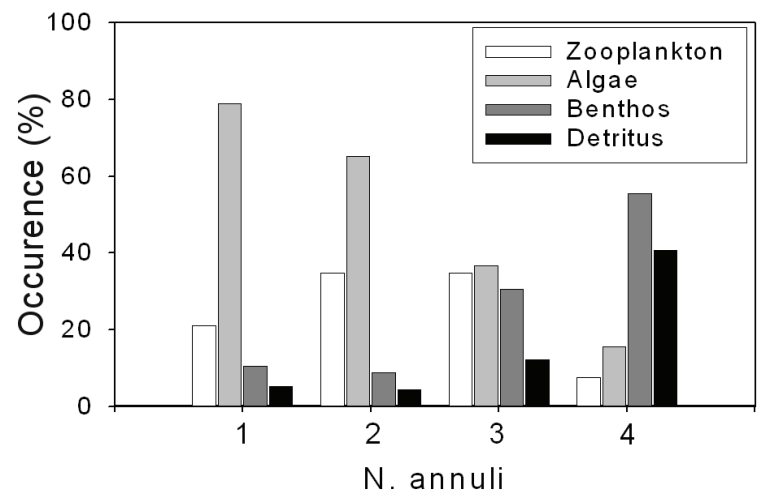

Fig. 4. Occurrence (\%) of food categories in the diet of roach in relation to the age group of the fish. The number of age group corresponds to the number of annuli identified on scales.

Absolute fecundity is $13740 \pm 4700$ (S.D.) at age 3 and $14768 \pm 5642$ (S.D.) at age 4 and increases with size (linear regression, $r^{2}=0.75, n=20, P=0.001$ ). The regression is: $F_{a b s}=2737.1 \times L_{T}-40053$. Mean relative fecundity $F_{\text {rel }}$ is $166510 \pm 30309$ (S.D.) at the age 3 and $189382 \pm 25320$ (S.D.) at the age 4 .

\section{DISCUSSION AND CONCLUSIONS}

Like in most other southern European lakes, the fish community in Lago Maggiore consists of a mix of native and exotic species (Tab. 1). Apparently native and non-native species have been able to coexist without drastic changes in the whole community. Such changes may actually have occurred, however, in the absence of systematic monitoring, evidence of this is only circumstantial. The recent appearance of roach in Lago Maggiore has been a rather dramatic event and now roach seems to be the most abundant fish in the lake. If the roach population stabilises at a much lower abundance level than at present, "peaceful coexistence" may be observed, but if not, serious ecosystem effects may become evident. The roach has probably been introduced by anglers or more likely in water diverted from Lake Lugano to Lago Maggiore during a flood event. The appearance of roach in Lago Maggiore is hardly surprising, but its considerable success in establishing a very large population is unexpected. The basic biological features of the sampled roach may give some indications of the cause for such success.

The growth of roach in Lago Maggiore is higher than reported from most other European waters (Tab. 2). The $\Phi^{\prime}$ values increase from northern to southern Europe. Also the VBGF $k$ parameter, which determines how fast a fish approach $L_{\infty}$, is higher in the southern regions (Chappaz et al. 1989; Guhtruf 2002; this study) than in central or northern European countries (Kempe
1962; Cragg-Hine \& Jones 1969; Burrough \& Kennedy 1979; Wiesky \& Zalachovsky 2000). It is quite surprising that the growth of roach in the oligo-mesotrophic Lago Maggiore is only slightly lower than in the eutrophic Lake Lugano (Guthruf 2002), indicating an abundant food source in Lago Maggiore. Manca et al. (2007) have found that the recent increase in water temperature in Lago Maggiore during spring (due to climate changes) has caused earlier development and an increased density of cladocerans. For spring spawners, like roach, this can be a great advantage because the availability of food in the first life stages has great importance for the survival and growth of young larvae. Furthermore, in contrast to other cyprinids the temperature sensitivity (routine metabolic rate) of juvenile roach in the range between 5 and $10^{\circ} \mathrm{C}$ has been shown to be extremely high $\left(Q_{10}=5.8\right)$ suggesting an ability to efficiently utilise high plankton densities at low temperatures (Hölker 2006).

The diet of roach in Lago Maggiore seems rather similar to that reported in the literature (Niederholzer \& Hofer 1980; Rask 1989; Horppila 1998; Lappalainen et al. 2001; Guthruf 2002), but the roach in this study did not eat macrophytes, unlike in other lacustrine environments (Niederholzer \& Hofer 1980; Horppila 1998; Guhtruf 2002; Hölker et al. 2002). This may be due to the low abundance of aquatic plants in Lago Maggiore caused by low nutrient concentration of the lake, fluctuating water levels and the steep littoral zone as found by Niederholzer \& Hofer (1980) in a Tyrolese lake and by Garcia-Berthou (1999) in the Banyoles Reservoir.

The proportion of full guts increases with water temperature. This has been found in many fish species and also in roach (Hellawell 1972). It must be noted that the feeding activity of juvenile roach, even if decreased, remains quite high year round and the metabolism of roach remain high at low water temperatures $\left(4{ }^{\circ} \mathrm{C}\right.$ and $10{ }^{\circ} \mathrm{C}$, Van Dijk et al. 2002), close to the minimum water temperature $\left(6.5^{\circ} \mathrm{C}\right)$ of Lago Maggiore in winter.

Roach are omnivorous and able to modify the diet in relation to the food availability. Thus, Townsend et al. (1986) found that roach switched to copepods when the density of small cladocerans was lower than 40 ind $\mathrm{L}^{-1}$. Giles et al. (1990) found that roach in two British lakes fed on Daphnia sp. or on Spyrogira sp. depending on their abundance. Also in Lago Maggiore the roach diet changes seasonally from benthos-based towards zooplankton-based when the lake productivity becomes higher. The same seems to apply for the presence of detritus in winter. When the lake productivity is low, as in winter and early spring, the roach switch to all available food resources, in order to optimize energy intake or they even abandon the lake (and feeding) to seek refuge from predation in small streams, canals or backwaters (Jepsen \& Berg 2002).

Fecundity values are quite high and more similar to those found in mesotrophic or eutrophic lakes or reser- 
Tab. 2. VBGF parameters and $\Phi^{\prime}$ values of different roach populations in northern emisphere. $(\mathrm{r})=$ river, $(\mathrm{O})=$ oligotrophic environment, $(\mathrm{E})=$ eutrophic environment; $\mathrm{F}=$ France, $\mathrm{S}=$ Sweden, $\mathrm{GB}=$ Great Britain; $\mathrm{NL}=$ Nederland; $\mathrm{P}=$ Poland, $\mathrm{CH}=$ Switzerland.

\begin{tabular}{|c|c|c|c|c|c|}
\hline Site & $L_{i n f}$ & $k$ & $t_{0}$ & $\Phi^{\prime}$ & Reference \\
\hline Malaren, S & 25.6 & 0.16 & -0.63 & 2.02 & Kempe 1962 \\
\hline Slapton Lay, GB & 22.95 & 0.20 & 0.20 & 2.02 & Burrough \& Kennedy 1979 \\
\hline Lake Dabie, $\mathrm{P}$ & 26.3 & 0.156 & -1.172 & 2.03 & Wiesky \& Zalachovsky 2000 \\
\hline Szczecin Lagoon, $\mathrm{P}$ & 23.7 & 0.242 & 0.008 & 2.13 & Wiesky \& Zalachovsky 2000 \\
\hline Pomerianian Bay, P & 33.2 & 0.139 & -0.299 & 2.14 & Wiesky \& Zalachovsky 2000 \\
\hline Tjeukemeer, NL & 20.65 & 0.23 & -0.23 & 1.99 & Goldspink 1979 \\
\hline Lago St. Croix, F (O) & 28.38 & 0.29 & 0.18 & 2.37 & Chappaz et al. 1989 \\
\hline Fotheringhay, GB (r) & 19.7 & 0.25 & 0.34 & 1.99 & Cragg-Hine \& Jones 1969 \\
\hline Lake Aydat, F & 25.6 & 0.16 & -0.63 & 2.02 & Jamet et al. 1994 \\
\hline Lake Geneve F (E) & 34.44 & 0.21 & -0.26 & 2.40 & Ponton \& Gerdeaux 1990 \\
\hline Lago di Lugano, $\mathrm{CH}$ & 36.8 & 0.3 & / & 2.61 & Guthruf 2002 \\
\hline Lago Maggiore & 35.75 & 0.29 & -0.40 & 2.55 & This study 2006 \\
\hline
\end{tabular}

voirs (Vollestadd \& L'Abbe-Lund 1990; Jamet \& Desmolles 1994; Guhtruf 2002) than reported from oligotrophic lakes (Tarkan 2006). Fecundity, feeding and spawning strategies are the most important features for success when a population is newly establishing. Roach are able to use a wide range of spawning grounds such as bedrocks, sand or mud (Volta pers. obs.). This gives the roach an advantage against the rudd which is a typical phytophilic fish species (Niederholzer \& Hofer 1980; Ravera \& Jamet 1991; Garcia-Berthou \& Moreno-Amich 2000). Moreover, roach spawn between March and late May, at least one month earlier than rudd and bleak. This is an advantage because roach larvae have the possibility to use the seasonal lake production earlier than rudd and bleak. Indeed, as have been found by Guhtruf (2002) in Lago di Lugano, roach larvae are found in the littoral zones one month earlier than rudd and bleak larvae.

According to Moss (2008) a reservoir is a disabled lake due to the lack of a true littoral zone caused by unnatural fluctuations in water level, resulting in a sterile shoreline, sometimes dry, sometimes flooded but with no predictable pattern to which organisms can adjust. The artificial water level fluctuations in Lago Maggiore may be an advantage for roach in competition with other species because roach are highly flexible in their habitat use (Brenner 1973; Gliwicz et al. 2000; Jacobsen et al. 2004). Pike is a principal important predator for roach, but pike are not very abundant in Lago Maggiore, despite sporadic fry stockings (A. Calderoni, pers. comm.), and the apparent decrease in the pike population (possibly caused by fluctuating water levels) may be of benefit for the roach.

The present results may not be representative for the whole lake, but they indicate an overwhelming abundance of roach compared to perch. It is likely that a large roach population will have a serious negative effect on the perch population. Both fishes are omnivorous, coexisting currently in an intraguild predation system (IGP) where perch becomes a top predator and roach is intermediate consumer (IC). The two species are engaged in a predator-prey interaction but also com- pete for basic resources. Perch is zooplanktivorous and benthivorous before switching to piscivory. As pointed out by Van de Wolfshaar et al. (2006) and Persson et al. (2007a) size dependent food web interactions can inhibit coexistence of top predator and IC in intraguild predation systems with life history omnivory. At small sizes, the predator may compete with its prey whereby the prey may limit the extent to which predator individuals are recruited to larger predatory stages, inducing an interspecific juvenile bottleneck in the predator (Neill 1975; Olson 1996; Byström et al. 1998). Analyses of IGP models (Persson et al. 2007a) shows that at low productivity levels, the top predator cannot persist, either because the availability of resources is too low for its existence or because it is out-competed by the intermediate consumer, despite the fact that the system provides enough resources for its persistence. Lago Maggiore perch also prey on bleak and on the freshwater blenny (P. Volta, unpubl.). Thus, the predation pressure on roach may not be as heavy as in other lakes of the same trophic status, where the roach is the main prey for piscivorous perch.

The roach population in Lago Maggiore is practically unimpacted by fishing. The minimum legal mesh size $(25 \mathrm{~mm})$ of gillnets, used by commercial fishermen principally for perch, selects roach at the mean $L_{T}$ of $21.2 \mathrm{~cm}$, which is over its length at maturity. This means that most roach have at least one spawning season before becoming liable to capture in the nets.

Interestingly, the very recent invasion of roach in Lago Maggiore corresponds both with the sharp decrease of fishing pressure and with the return of the lake to an oligotrophic state, which occurred in the 90s. As pointed out above, in the light of IGP view, the oligotrophic status of Lago Maggiore seems to be more beneficial for the roach than other fish species and in particular perch.

How the roach will influence the native Rutilus species in Lago Maggiore is not known. Due to very limited information it is mainly speculation, but the last ten years their abundance has decreased. Only one R. pigus and one $R$. aula were captured in the fish survey nets. It 
is known that roach can hybridize with $R$. pigus, i.e. it happens in Lago di Como (Romanò, pers. com). This could also be a problem for the persistence of the endemic R. pigus in Lago Maggiore.

In conclusion there has been a genuine invasion of roach into Lago Maggiore and through the last few years this exotic species have become dominant in the area surveyed. The reason is largely unknown and the ecological effects can only be surmised. The roach grow fast; have high fecundity and low mortality; conditions within the lake appear to be optimal for colonisation. Population control through predation or fishing is not evident, therefore the number of roach in the lake is not likely to decrease significantly in the near future.

In general the fish community in Lago Maggiore seems to be unstable, probably due to interspecific competition in littoral fish species and hydromorphological pressures that, through water level fluctuations, have crippled the littoral zone. The variation in nutrient load and the swing between oligo- and mesotrophic conditions has also played a role in destabilising the fish fauna. Predator stocking and prey culling can be used as management tools to counteract low levels of top predators. It has been shown (de Roos \& Persson 2002; de Roos et al. 2003) that piscivore stocking must be very intense to be successful and hence is not a practical management strategy in large lakes. Prey culling may be a more realistic approach to improve the status of fish stock in a sustainable way and promote predator recovery (Persson et al. 2007b). The data collected in this study merely provides a starting point in the exploration of the ecology of Lago Maggiore's fish community and its dynamics. Standardized fish monitoring, as required by the Water Framework Directive, must be regularly performed in the future to follow the development of the fish community in Lago Maggiore.

\section{REFERENCES}

Banarescu, P., M. Blanc, J.L Gaudet. \& J.C. Hureau.1971. European Inland Water Fish: a multilingual catalogue. EIFAC/FAO, Oxford: Fishing News Books: 130 pp.

Bettinetti, R., V. Croce, S. Galassi \& P. Volta. 2006. pp'DDT and pp'DDE accumulation in a food chain of Lake Maggiore (Northern Italy): testing steady-state condition. Environ. Sci. Poll. Res., 13: 1-8.

Bianco, P.G. 1998. Freshwater fish transfers in Italy: history, local modification of fish composition, and a prediction on the future of native populations. In: Cowx, J. (Ed.), Stocking and Introductions of Fishes. Oxford: Fishing News Books: 165-197.

Bianco, P.G. \& V. Ketmaier. 2001. Anthropogenic changes in the freshwater fish fauna of Italy, with reference to the central region and Barbus graellsii, a newly established alien species of iberian origin. J. Fish Biol., 59:190-208.

Brenner, T. 1973. Die Auswirkung der Eutrphierung des Bodensees auf Nahrung und Wachstum der Plötze (Rutilus rutilus). Fischwirt, 23: 98-99.

Burrough, R.J. \& C.R. Kennedy. 1979. The occurrence and natural alleviation of stunting in a population of roach, Rutilus rutilus (L.). J. Fish Biol., 15: 93-110.
Byström, P., L. Persson \& E. Wahlström. 1998. Competing predators and prey: juvenile bottlenecks in whole-lake experiments. Ecology, 79: 2153-2167.

Cambray, J.A. 2003. Impact on indigenous species biodiversity caused by the globalisation of alien recreational freshwater fisheries. Hydrobiologia, 500: 217-230.

Chappaz, R., G. Brun \& G. Olivari. 1990. Les fecterus de developement du gardon (Rutilus rutilus (L.)), introduit dans une retenue oligotrophe recente: analyse des parametres mesologiques (temperatures) et biologiques. C.R. Acad. Sci. (III), 310: 27-33.

Cragg-Hine, D. \& J.W. Jones. 1969. The growth of dace (Leuciscus leuciscus L.), roach (Rutilus rutilus L.) and chubb Squalius cephalus (L.) in willow Brook, Northamptonshire. J. Fish Biol., 1: 59-82.

Delmastro, G.B. \& G.A.C. Balma. 1991. Nota sulla comparsa del ciprinide transalpino Rutilus rutilus (Linnaeus, 1758) nelle acque piemontesi. Riv. Idrobiol., 29: 163-167.

de Roos, A.M. \& L. Persson. 2002. Size-dependent life-history traits promote catastrophic collapses of top predators. Proc. Nat. Acad. Sci., 99: 12907-12912.

de Roos, A.M., L. Persson \& H.R. Thieme. 2003. Emergent Allee effects in top predators feeding on structured prey populations. Proc. R. Soc. Lond., 270: 611-618.

Froese, R. \& C. Binohlan. 2000. Empirical relationships to estimate asymptotic length, length at first maturity and length at maximum yield per recruit in fishes, with a simple method to evaluate length frequency data. J. Fish Biol., 56: 758-773.

Galassi, S., G. Gandolfi. \& G. Pacchetti. 1981. Chlorinated hydrocarbons in fish from the River Po (Italy). Sci. Total Environ., 20: 231-235.

Garcia-Berthou, E. 1999. Spatial heterogeneity in roach (Rutilus rutilus) diet among contrasting basins whitin a lake. Arch. Hydrobiol., 146: 239-256.

Garcia-Berthou, E. \& R. Moreno-Amich. 2000. Rudd (Scardinius erythrophthalmus) introduced to the Iberian peninsula: feeding ecology in Lake Banyoles. Hydrobiologia, 436: 159-164.

Gherardi, F., S. Bertolino, M. Bodon, S. Cesellato, S. Cianfanelli, M. Ferraguti, E. Lori, G. Mura, A. Nocita, N. Riccardi, G. Rossetti, E. Rota, R. Scalera, S. Zerunian \& E. Tricarico. 2008. Animal xenodiversity in Italian inland waters: distribution, modes of arrival, and pathways. Biol. Invasions, 10: 435-454.

Gibson, R.J. \& R.L. Haedrich. 1988. The exceptional growth of juvenile atlantic salmon in the city waters of St. John's Newfouland, Canada. Pol. Arch. Hydrobiol., 35: 385-407.

Giles, N., M. Street \& R.M. Wright. 1990. Diet composition and prey preference of tench, Tinca tinca (L.), common bream, Abramis brama (L.), perch, Perca fluviatilis (L.) and roach, Rutilus rutilus (L.) in two contrasting gravel pit lakes: potential trophic overlap with wildfowl. J. Fish Biol., 37: 945-958.

Gliwicz, Z.M., A.E. Rutkowska. \& J. Wojciechowska. 2000. Daphnia populations in three interconnected lakes with roach as the principal planktivore. J. Plankton Res., 22: 1539-1557.

Goldsping, C.R. 1979: The population density growth rate and production of roach Rutilus rutilus L. in Tjeukemeer. The Netherlands. J. Fish. Biol., 15: 473-498.

Goren, M. \& B.S. Galil. 2005. A review of changes in the fish assemblages of Levantine inland and marine ecosystems following the introduction of non native fishes. J. App. Ichthyol., 21: 364-370.

Guthruf, J. 2002. Die Biologie des Rotauges im Luganer-see (Kanton TI). BUWAL, Mitt. Fisch., 74: 89 pp.

Hellawell, M. 1972. The growth, reproduction and food of the roach, Rutilus rutilus (L.) of the river Lugg, Herefordshire. J. Fish Biol., 4: 469-486. 
Hölker, F., S.S. Haertel, S. Steiner \& T. Mehner. 2002. Effects of piscivore-mediated habitat use on growth, diet and zooplankton consumption of roach: an individual-based modelling approach. Freshwat. Biol., 47: 2345-2358.

Hölker, F. 2006. Effects of body size and temperature on respiration of common bream compared to sympatric roach. Anim. Biol., 56: 23-37.

Horppila, J. 1998. Effects of mass removal and variable recruitment on nutrient excretion by a planktivorous roach stock. J. Fish Biol., 52: 951-961.

Jamet, J.L. \& F. Desmolles. 1994. Growth, reproduction and Condition of Roach (Rutilus rutilus L.), Perch (Perca fluviatilis L.)and Ruffe (Gymnocephalus cernuus L.) in eutrophic Lake Aydat (France). Int. Rev. Ges. Hydrobiol., 79: 305-322.

Jackson, D.A. \& H.H. Harvey. 1989. Biogeographic association in fish assemblages: local vs regional processes. Ecology, 70: 1472-1484.

Jacobsen, L., S. Berg, N. Jepsen \& C. Skov. 2004. Does roach behaviour differ between shallow lakes of different environmental state? J. Fish Biol., 65: 135-147.

Jepsen, N. \& S. Berg. 2002. The use of winter refuges by roach tagged with miniature radio transmitters. Hydrobiologia, 483: 167-173.

Kempe, O. 1962. The growth of the roach (Leuciscus rutilus L.) in some swedish lakes. Rep. Inst. Freshw. Res. Drottn., 44: $42-104$

Kottelat, M. \& J. Freyohf. 2007. Handbook of European freshwater fishes. Kottelat, M. Cornol, Switzerland \& Freyhof, J. Berlin, Germany, (Eds): 646 pp.

Lappalainen, A., M. Rask, H. Koponen \& S. Vesala. 2001. Relative abundance, diet and growth of perch (Perca fluviatilis) and roach (Rutilus rutilus) at Tvärminne, northern Baltic Sea, in 1975 and 1997: responses to eutrophication? Boreal Env. Res., 6: 107-118.

Manca, M., B. Torretta, P. Comoli, S.L. Amsinck \& E. Jeppesen. 2007. Major changes in trophic dynamics in large, deep sub-alpine Lake Maggiore from 1940s to 2002: a high resolution comparative palaeo-neolimnological study. Freshwat. Biol., 52: 2256-2269.

Marshall, T.R. \& P.A. Ryan. 1987. Abundance patterns and community attributes of fishes relative to environmental gradients. Can. J. Fish. Aquat. Sci., 44:198-215.

Mosello, R. \& G. Giussani. 1997. Evoluzione recente della qualità delle acque dei laghi profondi sudalpini. Documenta Ist. ital. Idrobiol., 61: 1-79.

Mosello, R. \& D. Ruggiu. 1985. Nutrient Load, trophic condition and restoration prospects of Lake Maggiore. Int. Revue ges.Hydrobiol. 70: 63-75

Moss, B. 2008. The kingdom of the shore: achievement of good ecological potential in reservoirs. Freshwat. Rev., 1: $29-42$.

Neill, W.E. 1975. Experimental studies of microcrustacean competition, community composition and efficiency of resource utilization. Ecology, 56: 809-826.

Niederholzer, R. \& R. Hofer. 1980. The feeding of roach (Rutilus rutilus L.) and rudd (Scardinius erythrophthalmus L.). I. Studies on natural populations. Pol. J. Ecol., 28: 45-59.

Olson, M.H. 1996. Predator-prey interactions in size-structured fish communities, implications of prey growth. Oecologia, 108:757-763.

Pauly, D. 1980. On the interrelationships between natural mortality growth parameters and mean environmental temperature in 175 fish stocks. J. Cons. Internat. Exp. Mer, 39: $175-179$.

Received: June 2008

Accepted: August 2008
Pauly, D. \& J.L. Munro. 1984. Once more on the comparison of growth in fish and invertebrates. Fishbyte, 2: 21-22.

Persson, L. 1997. Competition, predation and environmental factors as structuring forces in freshwater fish communities: Sumari (1971) revisited. Can. J. Fish. Aquat. Sci., 54: 85-88.

Persson, L., A.M. De Roos \& P. Byström. 2007a. State-dependent invasion windows for prey in size-structured predator-prey systems: Whole lake experiments. J. An. Ecol., 76: 94-104.

Persson, L., P.A. Amundsen, A.M. De Roos, A. Klementsen, R. Knudsen \& R. Primicerio. 2007b. Culling prey promotes predator recovery-alternative states in a whole lake experiment. Science, 316: 1743-1746.

Ponton, D. \& D. Gerdeaux. 1987. La population du gardon (Rutilus rutilus L.) du Lac Leman en 1983-85. Structure en age, determinisme du recrutement, analyse de la croissance. Bull. Fr. P. Piscic., 305: 43-53.

Rahel, F.J. 1986. Biogeographic influences on species composition of northern Wisconsin lakes with applications for lakes acidification studies. Can. J. Fish. Aquat. Sci., 43: 124-134.

Rask, M. 1989. A note on the diet of roach, Rutilus rutilus L., and other cyprinids at Tvarminne, northern Baltic Sea. Aq. Fen., 19: 19-27.

Ravera, O. \& J.L. Jamet. 1991. The diet of the rudd (Scardinius erythrophthalmus, L.) in relation to the possible consequences for the removal of this species from an eutrophic lake. Fund. App. Limnol., 123: 99-109.

Sparre, P. \& S.C. Venema. 1988. Introduction to tropical fish stock assessment. Part 1 Manual. Rev. 2. FAO. Fish. Tech. Pap. 306/1, 407p. FAO, Rome.

Tarkan, A.S. 2006. Reproductive ecology of two cyprinid fishes in an oligotrophic lake near the southern limits of their distribution range. Ecol. Freshw. Fish, 15: 131-138.

Tonn, W.M. \& J.J. Magnusson. 1982. Patterns in the species composition and richness of fish assemblages in northern Wisconsin lakes. Ecology, 63: 1149-1166.

Townsend, C.R., I.J. Winfield, G. Peirson \& M. Cryer. 1986. The response of young roach Rutilus rutilus to seasonal changes in abundance of microcrustacean prey: a field demonstration of switching. Oikos, 46: 372-378.

Van de Wolfshaar, K., A.M. de Roos \& L. Persson. 2006. Size-dependent interactions inhibit coexistence in intraguild predation systems with life-history omnivory. Am. Nat., 168: 62-75.

Van Dijk, P.L.M., G. Staaks \& I. Hardewig. 2002. The effect of fasting and refeeding on temperature preference, activity and growth of roach, Rutilus rutilus. Oecologia, 130: 496-504.

Vøllestad, L.A. \& J.H. L'Abée-Lund. 1990. Geographic variation in life-history strategy of female roach, Rutilus rutilus (L.). J. Fish Biol., 37: 853-864.

Volta, P. \& C. Romanò. 2007. Commercial fishing: a reliable tool for fish monitoring in Italy? Poster Session, FSAMLR Congress, Ceske Budejovice, 9-16 September 2007.

Von Bertalanffy, L. 1938. A quantitative theory of organic growth. Hum. Biol., 10: 181-213.

Volta, P., P. Tremolada, M.C. Neri, G. Giussani, S. Galassi. 2008. Age-dependent bioaccumulation of organochlorine compounds in fish and their selective biotransformation in top predators from Lake Maggiore (Italy). Wat. Air. Soil. Poll., Online first. DOI. 10.1007/s11270-008-9803-z.

Wiesky, K. \& W. Zalachovsky. 2000. Growth of roach Rutilus rutilus (L.) in the river Odra Estuary. Acta Icht. Pisc., 30: 3-17. 